\title{
Social Studies and Geography Teacher Candidates' Views on Coronavirus (COVID 19) and Online Education Process
}

\author{
Tuğba Cevriye ÖZKARAL ${ }^{1}$ \\ Necmettin Erbakan University, Konya, TURKEY
}

\author{
Recep BOZYíĞìT² \\ Necmettin Erbakan University, Konya, TURKEY
}

\begin{abstract}
${ }^{1}$ Corresponding author: Assist. Prof.. , Faculty of Education, Department of Turkish and Social Sciences Education, Necmettin Erbakan University, Konya, Turkey. tugbaozkaral [at] hotmail.com. ORCID: 0000-0003-4595-816X

${ }^{2}$ Assoc. Prof. , Faculty of Education, Department of Turkish and Social Sciences Education, Necmettin Erbakan University, Konya, Turkey rbozyigit [at]konya.edu.tr. ORCID: 0000-0002-9790-1168
\end{abstract}

\begin{abstract}
In Turkey, all universities started to carry out formal theoretical courses using online education methods after COVID19 pandemic. The aim of this study is to determine the views of Social Studies and Geography teacher candidates about COVID-19 and online education processes. To do so, a qualitative research method was used. The research working group, in the school year 2019-2020, were those studying to be Social Studies and Geography teachers at a Faculty of Education in a Turkish university. A total of 37 teacher candidates participated in the study and a questionnaire consisting of open-ended questions developed by the researcher was used to obtain their views. A content analysis process was used to analyze the data. According to the findings from the study, teacher candidates stated they were more affected by this process because they were in their final year of study. They explained the reason for this situation as being related to their internship being incomplete and their dreams of graduation being negatively affected. Furthermore, the lack of adequate internet access and connection problems experienced amongst the teachercandidates had a negative impact on their experience of online education processes. Therefore, according to the views of teacher-candidates. the process of considering the services, systems and infrastructure offered by the university needs to occur for effective online education processes to be developed. For example, providing training to Faculty members and providing facilities such as computers to minimize technical problems and solve problems related to lack of access. It is recommended that universities should improve their infrastructure and plan to train lecturers and teachers for online education processes. To do so will benefit both the experience of, and minimize concerns about, online education processes.
\end{abstract}

\section{Keywords}

Coronavirus, Social Studies, Geography, Teacher Candidates' Views, Online Education 
The novel coronavirus, COVID-19 spread around the world shortly after it appeared in Wuhan, China. It was declared to be a global pandemic by the World Health Organization (WHO) on 11 March 2020.

While the effects of the COVID-19 pandemic have yet to be fully understood, it is already clear that, as of mid-May 2020, the number of daily deaths due to COVID-19 is greater than deaths due to common causes such as malaria, suicide, road traffic accidents and HIV/AIDS (United Nations Development Program, 2020). The WHO (World Health Organization) has officially named this virus-infected pneumonia as "COVID-19". This acronym also covers the words corona, virus, disease, 2019 (year) together. In other words, COVID-19 is formed from "Co"of "Corona", "vi"of "virus", "d" of the English word "disease" meaning disease and "19" due to its first appearance in 2019 (Jianhua, 2020; Lovelace, 2020; Demir, Günaydın and Demir, 2020). COVID-19, is a highly contagious type of coronavirus that emerged in the shadow of the preparations for World War Three. It is a micro-organism that can only be seen with a microscope and can reproduce very quickly when it finds a breeding medium, so the fight against the virus is very difficult. Coronavirus also has a characteristic that targets every person regardless of any party, such as ideology, religion, age group, economic or social status (Alpgo and Oduncu Alpago, 2020). In this response, COVID-19 will be further abbreviated to CV-19.

Studies and published reports by the World Health Organization (WHO) have been followed with interest and concern by the whole world. According to the instructions of the WHO, national governments have taken and continue to take various measures against this new pandemic, which is spreading from China and threatening international public health. The goal was to protect public health, limit the impact of the virus, and ultimately enable the population to survive the pandemic with minimal damage. However, despite the solidification of measures against CV-19 on a global scale, the geographical impact of the pandemic and the continued increase in deaths associated with it have caused serious concern around the world (Acar, 2020). While CV-19 infection can cause mild illness in most people, it can affect some people more deeply and even result in death. Older people and those with pre-existing medical problems (such as cardiovascular disease, chronic respiratory disease or diabetes) are at serious risk (WHO, 2020).

In a globalized world, it is impossible for pandemic to be confined to a single region or a single country. It is not possible for anyone or any country to survive this alone. For the first time in the 21st Century, the world has been confronted with such a rapidly spreading and deadly and dangerous virus. The COVID 19 virus is not fully known to experts around the world, so scientific research continues. It is a known fact that global pandemics affecting large geographical areas and millions of people negatively affect social, political, cultural and economic life.

Humans are social creatures. Humans have basic needs such as nutrition and housing, but also other requirements such as education, entertainment, activities, artistic activities and tourist excursions. People need to socialize. Travel restrictions occurring during the pandemic period together with closure of schools, theatre and concert performances etc., means that daily life has become extraordinary because of such measures. Other measures include postponing artistic activities and sports competitions, and cancelling academic meetings (Özkoçak, Koç and Gültekin, 2020). 
The CV-19 pandemic, which deeply affected the whole world and Turkey, caused a significant change and transformation in our age and life; it also significantly affected education (Kırmızıgül, 2020). The CV-19 pandemic has caused the largest disruption of education in history, having already had a near universal impact on learners and teachers around the world, from pre-primary to secondary schools, technical and vocational education and training institutions, and also universities (United Nations, 2020). In this process, one of the first agenda items in many countries has been to ask the question about whether or not educational institutions can continue their activities. Education is one of the strongest predictors of the health and the wealth of a country's future workers, and the impact of long-term school closure on educational outcomes, future earnings, the health of young people, and future national productivity has not yet been quantified (Viner, Russell, Croker, Packer, Ward, Stansfield, Mytton, Bonell \& Booy, 2020).

Since the early Spring of 2020, Chinese universities have been experiencing an unprecedented massive "migration" from traditional in-class face-to-face education to online education. Due to the widespread nature of CV-19 in China, following the government's requirements of "nonstop teaching and learning", most Chinese universities started online education (Bao, 2020). Universities in Hong Kong decided that for the full Spring semester courses, teaching would occur completely online, although this was a temporary decision at the beginning of the pandemic. Combinations of asynchronous and synchronous modes of instruction were adopted (Moorhouse, 2020). The widespread and rapid expansion of the CV-19 across the world, including in Israel, has accelerated processes which have taken place in higher education overall, and in teacher education colleges in particular (DonitsaSchmidt \& Ramot, 2020).

In Turkey on 16 March 2020, all basic, secondary and higher education institutions, including pre-school education institutions, decided to suspend teaching for a period of three weeks. A quick increase in the number of CV-19 diagnosed cases in Turkey meant there was a further decision on 18 March 2020 for formal theoretical undergraduate and graduate programs of the University to be conducted through online education processes. Most recently, Council of Higher Education, decided that the Spring term education processes should be maintained only with online education, open education and digital education facilities (Karadağ and Yücel, 2020).

The term "online education" was first used in the 1892 catalogue of the University of Wisconsin in a 1906 paper by William Lighty, the administrator of the same university. The term gained widespread use in world scientific literature beginning in the 1960s (Adiyaman, 2002).

Today, online education is part of our country's enactment of higher education: associate degree, undergraduate completion, internet supported formal education undergraduate program, undergraduate and graduate programs (Akdemir, 2011).

The current health crisis is having a vast impact on students and youth globally. Confinement and social-distancing measures change the nature and processes of teaching and learning (Trade Union Advisory Committee, 2020). In this context, it is important to consider the teacher candidates ' thoughts about the online education 
process, together with how they perceive the process and their thoughts about online education overall. The general purpose of this study is to determine the views about CV-19 and the online education process from teacher candidates in Social Studies and Geography teachers who are residing in Turkey.

For this general purpose, answers to the following questions have been sought:

1. What are the Social Studies and Geography teacher candidates' views about the novel coronavirus (CV-19)?

2. How do Social Studies and Geography teacher candidates evaluate their experience of online education processes which occurred due to the coronavirus (CV-19)?

\section{Methodology}

\section{Research Design}

A qualitative research method was used in the current study. Phenomenology, one of the qualitative research patterns, was used in the research. Phenomenological approaches require methodological, painstaking, and in-depth portrayal and depiction of how people experience certain phenomena (Patton, 2014:104). This research also focused on how teacher candidates perceive, describe and evaluate the COVID-19 (CV-19) phenomenon.

\section{Participants}

The participant group for the current study consists of the final year teachercandidates in Social Studies and Geography who are studying in a Faculty of Education at a State University in Turkey during the 2019-2020 academic year. Due to restrictions imposed by the pandemic, the final year teacher-candidates were easily accessible by the appropriate sampling method and were therefore included in the study. In addition, it was thought that the ability of final-year teacher candidates would have mastered professional skills more than other candidates so they could provide richer data for research purposes. The descriptive data for the participant group are included in Table 1.

Table 1

Descriptive Data for the Participant Group

\begin{tabular}{ll}
\hline $\begin{array}{l}\text { Distribution of participants by } \\
\text { branch }\end{array}$ & frequency \\
$\begin{array}{l}\text { Geographical Education } \\
\text { Social Studies Education }\end{array}$ & 22 \\
$\begin{array}{l}\text { Distribution of participants by } \\
\text { gender }\end{array}$ & 15 \\
Female & frequency \\
Male & 17 \\
Age distribution of participants & 20 \\
Age range 21-24 & frequency \\
Age range 25-28 & 34 \\
Age 29 & 2 \\
& 1 \\
\hline
\end{tabular}


As shown in Table 1, 22 teacher-candidates participating in the research are studying in the Department of Geography Education; 15 teacher-candidates are studying in the Department of Social Studies Education. 17 teacher-candidates are female and 20 teacher-candidates are male. A total of 37 teacher-candidates participated in the research. The age-range is between 21-29 years old. The majority of teacher-candidates are 22 years old. 21 teacher-candidates who participated in the research stated that they lived in Konya while the other 16 teacher-candidates stated that they came to Konya from 14 different cities. All 16 teacher-candidates were forced to return to the cities where they lived according to the explanations made during the research process.

\section{Data Collection and Analysis}

A questionnaire consisting of open-ended questions developed by the researcher was used in order to obtain the views of the prospective teachers. The survey is conducted to obtain information from individuals verbally or in writing. The information requested from the individual may be of various kinds and include quantitative and qualitative data related to themself, their environment or their institution. This information is mainly obtained by meeting face-to-face, asking questions over the phone or via the internet (Arıkan, 2018). Open-ended questions are preferred so participants are asked to answer freely. There are three types of questions: interpretation, listing, and space filling. In the interpretation questions, it is aimed to gather more objective and detailed answers on a particular subject (Büyüköztürk, Kılıç Çakmak, Akgün, Karadeniz and Demirel, 2016).

During the development process of the questionnaire, the researchers conducted informal interviews about the difficulties experienced by prospective teachers during the COVID-19 (CV-19) pandemic and the resultant online education processes. Topics were determined and questions were created in this direction. Open-ended questions were preferred to those of the interpretation type. Questions were shared with an expert lecturer in the field of Educational Sciences and was broadly supported by the feedback received. The necessary arrangements were carried out by the researchers. The questionnaire contains five open-ended questions that ask how teacher candidates identify Coronavirus? together with how the pandemic affects their university and education lives and what their views are about online education?

With the occurrence of CV-19 cases in Turkey, curfew restrictions were imposed since 10 April 2020 throughout May and also June; therefore, it was not possible to obtain information and data by meeting face-to-face in this research. The data was obtained via electronic mail. Before beginning the data analysis, each teacher candidate's questionnaire was examined and the forms were coded. The forms are coded according to the Department in which they study and their gender; the codes are placed in a sequence, for example, SSTC $1 \mathrm{~F}$ means Social Studies teachercandidate number 1 female, and GTC 1M/ means Geography teacher-candidate number 1 male). The data collected through the questionnaire consisting of openended questions were subject to a content analysis process. The main purpose of content analysis is to reach concepts and relationships to explain the collected data. In content analysis it is important to identify the data so as to uncover facts that may 
be hidden within the data. The process is to bring together similar data within the framework of specific concepts and themes. These are then edited and interpreted in a way that the reader can understand (Yıldırım and Şimşek, 2011). In the current research, the code categories and themes revealed by content analysis are tabulated and presented in accordance with research questions.

Validity in qualitative research means that the researcher observes the phenomenon as it is and as impartially as possible (Yıldırım, 2010). In order to ensure the validity of this research, questionnaire forms were examined as they were and without any repercussions.

\section{Findings}

The content analysis results of the open-ended survey data are divided into themes, categories, codes and opinions. The frequencies of these opinions are found and presented below in parallel with the tables and research questions.

\section{The Views of Social Studies and Geography Teacher-Candidates About Coronavirus (CV-19)}

As a result of content analysis, under the theme of reflection on the coronavirus from teacher-candidates, categories of perceptions about CV-19, the impact of CV19 on their university life, the positive effects of CV-19 on individuals, and the main difficulties experienced in online education were reached.

Table 2

Social Studies and Geography Teacher-Candidate Views about Coronavirus (CV-19)

\begin{tabular}{|c|c|c|c|}
\hline Category & Code & Example & $\mathrm{f}$ \\
\hline \multirow{11}{*}{$\begin{array}{l}\text { Teacher } \\
\text { Candidates } \\
\text { COVID } 19 \\
\text { Perceptions }\end{array}$} & $\begin{array}{l}\text { Global } \\
\text { Pandemic }\end{array}$ & $\begin{array}{l}\text { They emphasize that the virus spreads } \\
\text { quickly and easily and affects the entire } \\
\text { world. }\end{array}$ & 11 \\
\hline & $\begin{array}{l}\text { Sociological } \\
\text { and economic }\end{array}$ & $\begin{array}{l}\text { They point out that all countries have } \\
\text { suffered huge economic losses and that }\end{array}$ & \\
\hline & harm & $\begin{array}{l}\text { there could be major economic changes } \\
\text { globally. They also express that there are } \\
\text { sociological difficulties in societies. }\end{array}$ & 6 \\
\hline & Disaster that & They emphasize that coronavirus causes & \\
\hline & negatively & people to experience uncertainty, fear, & 15 \\
\hline & $\begin{array}{l}\text { effects } \\
\text { psychology }\end{array}$ & $\begin{array}{l}\text { anxiety, despair, and therefore become } \\
\text { depressed. }\end{array}$ & \\
\hline & Deadly & They point out that the exact & 11 \\
\hline & & $\begin{array}{l}\text { unknown, that the drug and its treatment } \\
\text { are not yet certain, and that the pandemic } \\
\text { is a deadly disaster, thus causing a high } \\
\text { number of deaths. }\end{array}$ & 11 \\
\hline & Unexpected & They state that human beings have not & \\
\hline & & $\begin{array}{l}\text { been able to cope with this epidemic, that } \\
\text { they have been incapacitated and } \\
\text { therefore caught unprepared for the } \\
\text { coronavirus pandemic. }\end{array}$ & 8 \\
\hline & $\begin{array}{l}\text { Closure of } \\
\text { PPSE courses }\end{array}$ & $\begin{array}{l}\text { With the closure of PPSE courses that the } \\
\text { teacher candidates are in progress or are } \\
\text { considering applying for, it is emphasized }\end{array}$ & 6 \\
\hline
\end{tabular}


Özkaral, T. C., Bozyiğit, R. (2020). Social Studies and Geography Teacher Candidates' Views on...

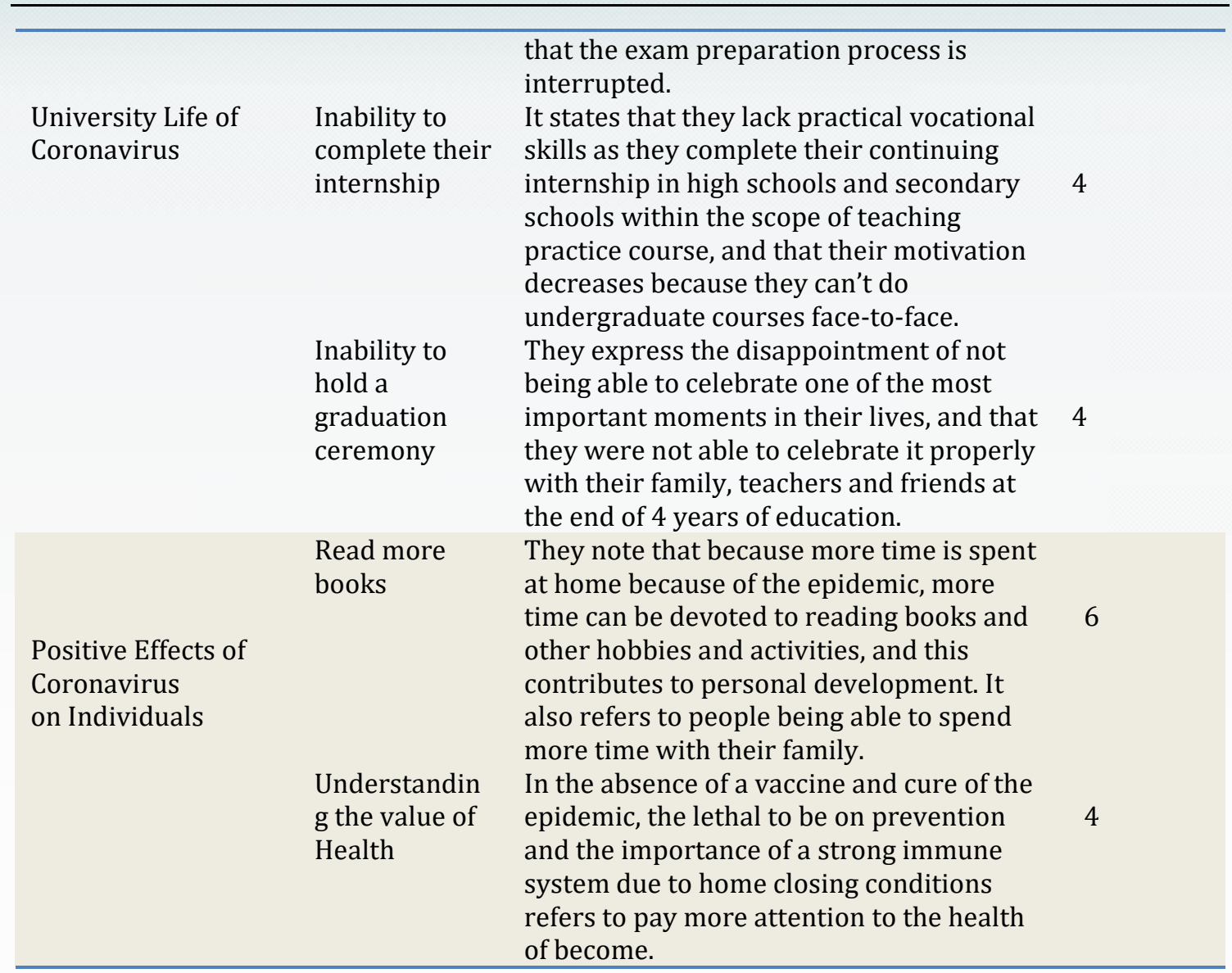

Many of the prospective teachers referred to COVID-19 as a deadly epidemic spreading rapidly around the world. However, the insights that come directly into these statements are codified as 'global epidemics', 'sociological and economic harm', 'catastrophe affecting psychology', 'fatal catastrophe' and 'unexpected perceptions. This information was presented in Table 2 under the COVID 19 perceptions category.

When the code for 'global epidemic' was addressed, 11 of the teacher-candidates expressed their views. Some excerpts of this situation are given below:

"Coronavirus spreads more rapidly from person to person than other viruses that have befallen humanity. Coronavirus is a serious concern because its rapid spread is extremely dangerous (GTC 1M)."

"Viruses are a threat to living things because they can reproduce in a way that is contrary to the control of living things. It has still not been definitively explained how the coronavirus (COVID 19) which emerged in December 2019. The virus has spread throughout the world in a short period of time because it cannot be determined how it spreads and how it damages it (GTC 4M)."

"It is a virus that has emerged in China, which is transmitted by means of a transmission that can reach large masses in a very short time and make them sick. Coronavirus is a global epidemic affecting our country and the world (GTC 5F)."

"I describe it as a type of disease that shows symptoms such as dry cough, fever, weakness, shortness of breath, loss of taste and smell. Coronavirus is a virus that is not limited to a single 
species. Other varieties have been encountered before. However, as COVID-19 was encountered for the first time, there is no specific vaccine or treatment. This disease is very easily transmitted from person to person under the influence of the whole world in a short time. Because of this risk, all over the world has been put on red alert and measures have been taken against this disease and its treatment is being investigated (SSTC 6F)."

"Coronavirus, which I describe as the so-called 'plague of the age' that has affected the world, is a type of infection that spreads rapidly, deadly enough to cause the destruction of human extinction if precautions were not taken throughout the world. The virus, which has killed many people, has revealed how small the globalized world is (GTC 6F)."

"Coronavirus is a very dangerous virus on a global scale. It is suitable for spreading and transmission very quickly due to respiratory transmission. This makes the virus much more dangerous." (GTC 7F)

"It is an organism that makes people ill and causes serious damage in people with weak immune systems, sometimes leading to death. Coronavirus is a disease that has spread all over the world with very high rates of transmission and mortality. The symptoms of this disease, in whom the disease is at first unclear who has the virus is moving not in an insidious way so it is not known, and thus is spreading to a lot more people (SSTC 8F)."

In the statements from six teacher candidates, the sociological and economic effects of COVID-19 are emphasized. Some excerpts of this situation are given below:

"Even the impact of nuclear weapons has not affected people in such a negative way. The sociological and economic damage has been enormous. Big states are using large parts of their economies for the pandemic. In the undeveloped countries, problems stemming from economic troubles have arisen (SSTC 1M)."

"An epidemic that has brought humanity to a standstill, disrupted economies and disrupted many countries" (GTC 8M).

"It is a global war that threatens human life and must be defeated by all humanity working in solidarity. As it affects all countries, it is a type of virus that threatens our country, both economically and socially, and that cannot be found in medicine" (GTC 9F).

"My family was unemployed because we got along with tourism and I don't think we've seen enough help, so I can tell you that we're drifting towards the worst. These health and economic troubles continue to bring tons of problems, such as social and domestic." (GTC 9F)

When we look at the code about negative psychological effects, we see that 15 teacher- candidates have expressed such opinions including expressions of uncertainty, fear, anxiety, despair. Some views on this situation are as follows:

"Even though we are facing death at every moment, it is quite terrifying to live this way without knowing where to come from. It's like this reminds me of the apocalypse. There, everyone is afraid to come together in the world, just as they are going to run away from their own brother and their parents. There's always a disturbance. Now it's psychologically affected. We can say that people who are obsessed are becoming more obsessed (SSTC 3F)"

"Being locked up in my house, being away from socialization is a very stressful situation psychologically, and besides, the risk of contracting a disease is a different dimension of the job" (GTC 7M).

Eleven of the teacher-candidate participants stated that the pandemic was a particularly deadly disaster. The following is an excerpt from this situation:

"It is a pandemic that changes people's lives, leads to deaths, brings life to a standstill and puts countries and health sectors in a difficult position" (SSTC 7M). 
"It is a life-changing pandemic that has caused millions of fatal cases where antibiotics have no effect" (GTC 2M).

"The virus is a dangerous virus that spreads from an animal market in Wuhan, China, easily transmitted to humans through respiration or saliva. Coronavirus is a deadly virus that infects the world. The world did not take this virus seriously enough at first and is paying the price with casualties. People weren't ready to fight this virus, and they're just starting to learn how to fight it right now" (GTC 5M).

Considering the code for 'unexpected perceptions', eight of the teachercandidates expressed their opinions. They believe that this sudden pandemic has caused confusion, and that human beings have not been able to cope with it and are incapable of coping with it. Some excerpts of this situation are given below:

"I would describe it as a surprise. The world did not expect such a pandemic. And when it started, no one could have predicted the consequences. For this reason, the virus reminds me of an unexpected surprise. I believe it will make drastic changes in the world's order (GTC 8F)."

"It is an event that humanity cannot see and takes a lot of time to resolve, which shows how helpless people are." (SSTC 7F)

Teacher-candidates ' views about the impact of the epidemic on their university lives are covered under the codes of closure of Public Personnel Selection Examination (PPSE) courses, and their inability to complete their internships and non-regulation of graduation ceremonies (Table 2). Teacher candidates stated that they were more affected by this process because they were in their final year of study. They explained the reason for this situation as the closure of the PPSE courses they were attending, the completion of their internship and the negative impact of their dreams of graduation as final-year students of the university.

Six of the teacher-candidates have expressed their views about the code of closure of Public Personnel Selection Exam courses. Only one of the students (GTC 6F) saw the closure of the PPSE course as a negative situation although it was stated that they directed themself towards more disciplined individual work. Some excerpts of this situation are given below:

"In terms of education, I was negatively affected by my failing classes and the postponement of my Public Personnel Selection Exam. The constant fear of whether or not the virus is going to infect me is psychologically pulling me down a little bit" (GTC 3M).

"Since I was a senior in college, I was unable to complete my school, my internship, my private courses. I can't prepare for my exams" (GTC 5F).

"It's a very difficult situation for me to stay at home. Because I'm the kind of person who's always out in my normal life. When I was out all the time because of school and courses and stuff, I was seeing my friends once or twice a week. Now I can't get out of the House. And that affects me very badly psychologically. The fact that the educational institutions that we have to attend regularly, such as schools and courses, are closed has upset my life order. I regularly go to the course every day and study from morning to night and now I can't do anything. As someone who has never studied at home in my entire life, this process has been extra bad for me. I had planned to finish PPSE issues by May, and I was going according to my plans until the virus arrived in our country. But now I'm way behind my plans. That puts additional pressure on all negative situations" (GTC $10 \mathrm{M})$. 
"The closure of the classrooms as a result of the measures taken has pushed us into the programmatic teaching process for the PPSE process, our work continues individually" (GTC 6M).

When the teacher-candidate views about the code for 'failing to complete their internship' was taken into consideration, four of the teacher candidates expressed their opinions. Some views about this situation are as follows:

\begin{abstract}
"As a senior, I would say it was a big blow to our dreams and what we wanted to do. We were thinking of completing the last semester of our senior year together and spending a lot of time together, not leaving anything missing, but this epidemic that started suddenly, unfortunately, caused us to cancel all our plans. In addition, we went to the classroom for PPSE disrupted, our internships disrupted. Our internship plans were great. We were just beginning to swallow class dust, but that was unfinished" (GTC 8F).

"I'd say it was twice as bad as usual for us to be in senior year. Our courses are incomplete, our internship is incomplete, we are deprived of our school. I think it's hard to work alone without getting help, and I think that shows how important teachers are. The lack of an internship is a very big shortfall, our education is finished and completed before we can tell any lessons, and in my eyes, this is the biggest shortfall" (GTC 9F).
\end{abstract}

Four prospective teachers have expressed their views about not being able to hold a graduation ceremony. The following is an excerpt from this situation:

"It has obviously saddened me that we have experienced this situation in the last period of my education. As these events begin, the online education process has ended in my last term. I am deeply and deeply, deeply, deeply saddened that my four-year college life ended this way. Because my four years have brought me good friends and teachers. Unfortunately, ending the semester without saying goodbye to my friends and teachers was not the kind of graduation we expected. We've been deprived of a lot of the things we've arranged for graduation" (SSTC 5F).

"I'm a senior, and we graduate suddenly without a taste of anything. I'd like to spend the last time with my teachers, my friends, in a nice way" (GTC 6F).

The process has also had positive effects on teacher-candidates. In Table 2 , the positive effects of coronavirus on individuals were more in the category of reading books. An understanding about the codes related to the 'value of health' were revealed.

Six of the teachers stated that they were able to spend more time reading books during the COVID 19 process. Some excerpts of this situation are given below.

"I think this period is the opportunity for people to devote opportunities to actions such as reading, learning"(SSTC 1F).

"The only benefit of this virus to my life may be that I have regained the habit of reading from boredom" (GTC $4 \mathrm{M})$.

"In the process, we became more intertwined with our family and began to find new activities to spend time with. We had the opportunity to read books that we hadn't read, that we had postponed" (SSTC 5F).

"It had a positive effect, of course. I had the opportunity to read books that I couldn't read"(GTC 6F). 
"Instead of exams, we started doing homework. That was more positive for me. Because we had enough free time at home for homework. I spent my free time reading books and doing research"(SSTC 7M).

Finally, when the code about understanding the value of health was taken into consideration, four of the teacher-candidates expressed their opinions. Some excerpts of this situation are given below:

"Coronavirus has taught me that health and life are more important than anything else. I'm paying a little bit more attention to my health and it's been a good thing in this way"(GTC 2F).

"Coronavirus has enabled me to take many measures, especially in terms of Health. It's had a positive effect on my health"(SSTC 2M).

"There is a solution to everything in life, as long as the person is healthy. Once again, I saw that it was all about health" (GTC 6F).

\section{Assessment of Online Education Processes Experienced by Social Studies and Geography Teacher-Candidates Due to Coronavirus (CV-19)}

When the opinions of the teacher-candidates about their experience of online education related to COVID 19 were evaluated, the codes of 'no substitute for formal education', 'internet - hardware problems' and 'inequality of opportunity' were reached.

Table 3

Social Studies and Geography Teacher-Candidates Views' about Online Education due to Coronavirus (CV-19)

\begin{tabular}{|c|c|c|c|}
\hline Category & $\begin{array}{l}\text { Code } \\
\text { No } \\
\text { substitute } \\
\text { for formal } \\
\text { education }\end{array}$ & $\begin{array}{l}\text { Example } \\
\text { It is emphasized that the candidates cannot be } \\
\text { motivated in the online education process as they } \\
\text { are in face-to-face Education, stay away from } \\
\text { university life and culture, restrict the opportunity } \\
\text { for active learning, not being familiar enough with } \\
\text { online education and not preferring it. }\end{array}$ & 11 \\
\hline \multirow[t]{2}{*}{$\begin{array}{l}\text { Online } \\
\text { education } \\
\text { process }\end{array}$} & $\begin{array}{l}\text { internet- } \\
\text { hardware } \\
\text { issues }\end{array}$ & $\begin{array}{l}\text { It refers to hardware and internet interruptions that } \\
\text { occur from time to time during lessons or when } \\
\text { sending homework during online education. }\end{array}$ & 15 \\
\hline & $\begin{array}{l}\text { Inequality of } \\
\text { opportunity }\end{array}$ & $\begin{array}{l}\text { It states that some of the prospective teachers are } \\
\text { not able to make enough use of online education due } \\
\text { to lack of adequate financial and technological } \\
\text { facilities. }\end{array}$ & 6 \\
\hline
\end{tabular}

Eleven of the prospective teacher-candidates expressed their views and the code of 'no substitute for formal education' was revealed. Some excerpts of this situation are given below:

"Online education courses are insufficient in some ways. Because even though we have the opportunity to ask questions, there is no discussion like the one in the lessons" (SSTC3M).

"Now I feel like a child with a toy taken from my hand. Yes, education continues everywhere, but the peace and trust given by schools is a different place. I don't think it's as effective as face-toface training, no matter how much education is continued with online education" (SSTC3F). 
"Online education the support of our state and faculty offers us sufficient education through the efforts of our teachers. But of course, it doesn't quite replace the face-to-face training in the classroom" (GTC 10M).

"My school first took a 3-week. She then switched to online education. I don't know how long this process will continue. I think face-to-face training is better. We're continuing with online education now. Our teachers are trying to create as many opportunities as they can. I think it's negatively impacted my education life" (SSTC 6F).

"Because it is the first time, I have received online education, and because there is no classroom environment, I can not necessarily concentrate fully"(SSTC 7F).

"I don't think there's any substitute for the education we've had at school. I'd say you're more lacking in face-to-face training. And because it doesn't appeal to all sense organs, what we learn won't be permanent. A system that is always interrupted, which is very difficult to connect with when people's brains are numbed, will take people away from education" (SSTC 9F).

Fifteen teacher candidates expressed their views about the code related to 'internet-hardware problems'. The views of some of the participants are as follows:

"Even if we receive online education with a good system, we experience disconnections from time to time" (GTC 4F).

"Many problems arise because of the system in online education. The Voice of our teachers is often interrupted, sometimes the broadcast freezes, sometimes it turns off completely. So, I don't get as much efficiency as the classroom environment" (GTC $6 \mathrm{~F})$.

"But we often experience difficulties in the program used for online education. We're having a bit of a hard time getting into the system and freezing things" (GTC $7 F)$.

"Online education was not a system we were accustomed to as teachers and students. We've all suffered the inexperience of this, our teachers and US. The connection and sound problems are very elegant and we are living" (GTC 8F).

When addressing the 'inequality of opportunity' code, six of the teachercandidates expressed their views. Some excerpts of this situation are given below:

"Our education system has completely changed. This has affected us negatively. Most people are having problems because our lessons are remote. My friends couldn't attend because there was no internet shortage or possibility. I've had problems the same way"(SSTC4F).

"The opportunities where some of my friends live prevent them from joining the system and my friends are deprived of Education" (GTC 4M).

"Because I live in the village, I can't make enough use of online education as we have an internet shortage and this is a disadvantage for me"(GTC 5F).

\section{Conclusion, Discussion and Suggestions}

In this study, the views of Social Studies and Geography teacher-candidates regarding the novel coronavirus, COVID-19 (CV-19) and their experience of online education process were discussed. In the light of the findings obtained from the research, under the theme of reflection on CV-19, the responses from teacher- 
candidates reveal the categories of 'perceptions of coronavirus', 'impact of coronavirus on university life', 'positive effects of coronavirus on individuals' and 'main difficulties experienced in online education'.

Under the categories and codes of 'CV-19 perceptions of teacher candidates', 'global epidemic', 'sociological and economic harm', 'disaster affecting psychology', 'fatal disaster' and 'unexpected perceptions' the teacher-candidates described CV19 as dangerous and deadly, while also focusing on its economic and psychological effects. Some participants perceive the pandemic as a deadly disaster, while others think that the population is not ready for such as pandemic, and that the pandemic is an unexpected and bad surprise. Görgülü-Arı and Hayır-Kanat (2020) investigated the general thoughts of Social Studies and Science teacher-candidates during the COVID-19 pandemic and reached similar conclusions with this study; where the virus was described as a deadly pandemic affecting the whole world, and also touched on its psychological and economic effects.

Students across the higher education sector have been dramatically impacted by the spread of the CV-19, from travel restrictions to social distancing, isolation measures, quarantines, campus closures, and border closures (Quacquarelli Symonds, 2020). Inevitably, the loss of social contact and socialization routines will take its toll because they are part of the daily experience of a higher education student. The isolation that invariably comes with confinement will have an effect in terms of socio-emotional balance (United Nations Educational Scientific and Cultural Organization/ International Institute for Higher Education in Latin America and the Caribbean, 2020). The research conducted by Kara (2020) examined the impact of the COVID-19 pandemic process on students and evaluated many situations experienced by students. During the pandemic, students were found to feel most upset and uneasy during the day.

When statistics on the CV-19 pandemic are examined, the total death toll reaches 799,627 people (Worldometers, 2020). Whether from developed or emerging economies, the world economy as a whole has been negatively affected by CV-19. All sectors of the economy such as tourism, education, agriculture, energy, civil aviation, finance is negatively affected. Besides the socio-cultural and psychological consequences of the process, undoubtedly the biggest consequences are on the economy and it will continue to be affected in the near future (Duran \& Acar, 2020). Through the massive economic disruption, the CV-19 crisis is affecting the world's workforce of 3.3 billion people. Sharp and unforeseen reductions in economic activity are causing a dramatic decline in employment, both in terms of numbers of jobs and aggregate hours of work (International Labour Organization, 2020).

The codes for 'closing Public Personnel Selection Examination (PPSE) courses', 'failing to complete their internships' and 'not holding graduation ceremonies' occur under the category of 'impact of the epidemic on the university lives of teachercandidates'. Teacher-candidates stated they were more affected by this process because they were in their final year of study. They explained the reason for this situation as being related to the closure of the PPSE courses they were attending, their internship being halved, and their dreams of graduating being adversely affected. In Turkey, PPSE exam results are used by the Ministry of National 
Education for appointments to teacher positions. The teacher-candidates who apply for teacher positions via this exam must take part in the teaching field knowledge test depending on the General Ability-General Culture and Educational Sciences sessions of the exam and in their fields.

The International Association of Universities Global Survey Report results illustrate the important degree of stress and constraint currently being experienced by higher education institutions around the world. Almost all institutions that responded to the survey are affected by the COVID-19 (CV-19) crisis and the crisis has affected all institutional activities (International Association of Universities, 2020). Because of the pandemic, some universities have presented their online graduation ceremonies on their web pages for lecturers, students and their families to view. Online graduation ceremonies can be monitored with the help of the provided web links.

In the study, the positive effects of CV-19 on individuals were found in the category codes of 'reading more books' and 'understanding the value of health'. Teacher-candidates in their final year of study stated the impact of the pandemic has been for them to be reading more books in particular. It has also been seen that they understand the value of their health and pay more attention to their health. Students now have the autonomy and agency to take charge of their learning to explore new ideas and experiences like never before. New interests and passions will emerge for many students (Hundred, 2020).

In the research codes of 'non - formal education', 'internet-hardware problems' and 'inequality of opportunity' were reached under the category of 'online education process'. The lack of having access to the same financial and technological facilities by all teacher-candidates is said to negatively affect the online education process. Lack of adequate internet packages or problems with internet connection were among the factors contributing to a negative effect with the online education process. Karakuş, Ucuzsatar, Karacaoğlu, Esendemir and Bayraktar (2020) also studied Turkish teacher-candidates' views about online education processes and it was found that the most common technical glitches were internet/connection problems and unsupported devices/hardware deficiencies.

In the current research, the teacher-candidates stated that online education is not as effective and efficient as face-to-face education. Arı and Dönel-Akgül (2020) examined the views of Secondary School students about the provision of a Science course through online education during the CV-19 pandemic and in a similar way, students expressed their preference for face-to-face education. Students emphasized their preference for education to occur in school because one-to-one training and experimentation in school gives them a better understanding about the subjects, motivates them to learn, and makes the lessons more fun and social.

The use of technology in education has become quite important in recent years. The main objective of using technology in education is to improve the existing conditions, increase the efficiency of education, and support the education and training processes (Koç and Daşdemir, 2016). In the 21st Century - the information age - the information and communication technologies are developing rapidly. Such developments have also contributed significantly to the development of online 
education applications and the Global Communication Network. Online education practices, which were considered utopia for societies in the past, have become easily applicable today with the developments in Information Technologies (İșman, 2011). The most important aim of online education models is that a large audience receives the necessary training regardless of location and time. This flexibility makes it easier to receive the training (Dinçer, 2016). However, online education seems unlikely to achieve the learning outcomes on an equal measure compared to face-to-face education (Karataş, 2003).

The lack of having access to the same financial and technological facilities for all teacher-candidates had a negatively affected on the online education process experienced by the teacher-candidates. The lack of adequate internet packages and connectivity problems have also come to the fore. The technical requirements of online teaching are far greater than traditional in-class teaching for inexperienced faculty members. In view of the fact that most of the Faculty at a university are insufficiently trained or supported to operate online education platforms, the support from teaching assistants is particularly important (Bao, 2020).

On 29 April 2020, the Higher Education Council stated; "https://yokdersleri.yok.gov.tr you will be able to access the content of our universities, which you can access at the address, within the scope of the "Online education Support" quota of $6 \mathrm{~GB}$, which will be defined by your mobile operators free of charge on your lines" (Council of Higher Education, 2020). This practice is thought to be positive and in place. According to Karadağ and Yücel (2020), students who do not have computers and tablets in particular should be allowed to acquire cheap and advanced Pay-Per-View computers and tablets.

Such support affected students through effective remote learning opportunities. Public institutions and the private sector can be called upon to donate the equipment needed for remote learning such as computers, tablets, smartphones, fees for the instalment and subscription to internet (Organization for Economic Cooperation and Development, 2020). Governments in developing countries should also look at ways to mobilize additional resources from non-traditional sources (such as philanthropic organizations or corporate social responsibility contributions) to support investments in the education sector (World Bank Group Education, 2020).

Based on the findings of the study the following suggestions are offered:

- It is recommended for universities to provide psychological help and courses to help eliminate the feelings of fear, anxiety, hopelessness in this online education process.

- In order for teachers and teacher-candidates to have positive thoughts towards online education, the online education environments should be created where technical problems are minimized. Additionally, necessary measures should be taken regarding provision of facilities such as computer, internet access, etc.

- It is considered necessary to provide in-service training to teachers and faculty members about the provision of online education. 


\section{References}

Acar, Y. (2020). The novel coronavirus (Covid-19) outbreak and impact on tourism activities. Journal of Contemporary Tourism Research, 4(1), 7-21.

Adiyaman, Z. (2002). Teaching foreign languages via distance education. The Turkish Online Journal of Educational Technology, 1(1), 11-92.

Akdemir, Ö. (2011). Distance education in Turkish higher education. Journal of Higher Education and Science, 1(2), 69-71.

Alpgo, H. \& Oduncu Alpago, D. (2020). Socio-economic consequences of coronavirus. IBAD Journal of Social Sciences, 8, 99-114.

Altun Ekiz, M. (2020). The views of physical education and sports school students about distance education in the quarantine period (a qualitative research). Journal of Sport and Recreation Researches, 2(ÖS1), 1-13.

Arıkan, R. (2018). A general review on interview techniques. Halic University Journal of Social Sciences, 1, 97-159.

Bao, W. (2020). COVID-19 and online teaching in higher education: a case study of peking university. Human Behavior and Emerging Technologies, 2, 113-115.

Büyüköztürk, Ş., Kılıç Çakmak, E., Akgün, Ö.E., Karadeniz, Ş. \& Demirel, F. (2011). Scientific research methods. Ankara: Pegem Academy.

Council of Higher Education (2020). Education Support Quota for Students. www.yok.gov.tr

Crawford, J., Butler-Henderson, K., Rudolph, J., Malkawi, B., Glowatz, M., Burton, R., et al. (2020). COVID-19: 20 countries' higher education intra-period digital pedagogy responses. Journal of Applied Learning \& Teaching, 3(1), 9-28. https://doi.org/10.37074/jalt.2020.3.1.7

Creswell, J. C. (2017). 30 basic skills for qualitative researchers. (H. Özcan, Trans. Ed.). Ankara: Anı

Demir, M., Günaydın, Y. \& Demir, S..Ş. (2020). The evaluation of the antecedents, effects and consequences of coronavirus (Covid-19) pandemic on tourism in Turkey. International Journal of Social Sciences and Education Research, 6(1), 80-107.

Dinçer, S. (2006). An overview of computer assisted education and distance learning. Information Technologies Congress IV/ Academic Informatics. Denizli: Pamukkale University.

Donitsa-Schmidt, S. \& Ramot, R. (2020). Opportunities and challenges: teacher education in Israel in the Covid-19 pandemic. Journal of Education for Teaching. https://doi.org/10.1080/02607476.2020.1799708.

Duran, M.S. \& Acar, M. (2020). What a virus could do the world: macroeconomic effects of Covid-19 pandemic. International Journal of Social and Economic Sciences, 10(1), 5467.

European Commission Joint Research Centre (2020). The likely impact of COVID-19 on education: reflections based on the existing literature and recent international datasets. Retrieved from https://publications.jrc.ec.europa.eu/repository/ 
Görgülü-Arı, A. \& Hayır-Kanat. M. (2020). Prospective teacher' views on Covid-19 (coronavirus). Van Yüzüncü Yıl University the Journal of Social Sciences Institute, Outbreak Diseases Special Issue, 459-492.

HundrED (2020). Spotlight: quality education for all during Covid-19 crisis. Retrieved from https://hundred.org/en

International Association of Universities (2020). The impact of Covid-19 on higher education around the World. Retrieved from https://iau-aiu.net/

International Labour Organization (2020). ILO Monitor: COVID-19 and The World of Work. Second edition. Updated Estimates and Analysis. Retrieved from https://www.ilo.org/global/lang--en/index.htm

İşman, A. (2011). Distance education. Ankara: Pegem Academy.

Jianhua, G. (2020). China's war against new coronavirus pneumonia: the struggles, consequences and reflections. (M. E. Başer \& D. Doğu, Trans. Ed.). BRIQ (Belt \& Road Initiative Quarterly), 1(2), 91-102.

Johnson, B. \& Christensen, L. (2014). Educational research quantitative, qualitative, and mixed approaches (4th Edition), (S. B. Demir, Trans. Ed.). Ankara: Eğiten Kitap.

Kara, Y. (2020). Students' Experiences in the pandemic duration: the case of Bakirköy district. Eurasian Journal of Researches in Social and Economics (EJRSE), 7(7), 165176.

Karadağ, E., \& Yücel, C. (2020). Distance education at universities during the novel coronavirus pandemic: an analysis of undergraduate students. Journal of Higher Education, 10(2), 181-192.

Karakuş, N., Ucuzsatar, N., Karacaoğlu, M. Ö., Esendemir, N. \& Bayraktar, D. (2020). Turkish teacher candidates' views on distance education. RumeliDE Journal of Language and Literature Studies, 19, 220-241. DOI: 10.29000/rumelide.752297.

Karataş, S. (2003). The equivalency of learning experiences in distance and face to face education. Educational Sciences and Practice, 2(3), 91-104.

Kırmızıgül, H.G. (2020). The Covid-19 pandemic and the resulting education process. Eurasian Journal of Researches in Social and Economics (EJRSE), 7(5), 283-289.

Koca, N. \& Daşdemir, İ. (2016). A new technology for social sciences teaching geographic information system. The Journal of Academic Social Science Studies, 50, 483-496,

Kürtüncü, M.\& Kurt, A. (2020). Problems of nursing students in distance education in the covid-19 pandemic period. Eurasian Journal of Researches in Social and Economics (EJRSE), 7(5), 66-77.

Lovelace B. (2020). World Health Organization names the new coronavirus: COVID-19. Retrieved from https://www.cnbc.com/.

Moorhouse, B. L. (2020). Adaptations to a face-to-face initial teacher education course 'forced' online due to the COVID-19 pandemic. Journal of Education for Teaching. https://doi.org/10.1080/02607476.2020.1755205

Organization for Economic Co-operation and Development (2020). COVID-19: protecting people and societies. Retrieved from https://www.oecd.org/coronavirus/policyresponses/covid-19-protecting-people-and-societies-e5c9de1a/ 
Özkoçak, V., Koç, F. \& Gültekin T. (2020). Anthropological overview of pandemics: coronavirus (Covid-19) example. Turkish Studies, 15(2), 1183-1195.

Patton, M. Q. (2014). Qualitative research and evaluation methods. (M. Bütün \& S. B. Demir, Trans. Ed.) Translation from 3rd Edition, Ankara: Pegem Academy.

Pınar, M. A. \& Dönel Akgül, G. (2020). The opinions of secondary school students about giving science courses with distance education during the covid-19 pandemic. Journal of Current Researches on Social Sciences, 2020, 10(2), 461-486.

Quacquarelli Symonds (2020). The impact of the coronavirus on global higher education. Retrieved from https://www.qs.com/

Trade Union Advisory Committee (2020). Impact and implications of the COVID 19-crisis on educational systems and households. Retrieved from https://tuac.org/news/page/3/

United Nations (2020). Policy brief: education during COVID-19 and beyond. Retrieved from https://www.un.org/en/coronavirus/future-education-here

United Nations Development Program (2020). COVID-19 and human development: assessing the crisis, envisioning the recovery. Retrieved from http://hdr.undp.org/

United Nations Educational Scientific and Cultural Organization/ International Institute for Higher Education in Latin America and the Caribbean (2020). COVID-19 and higher education: today and tomorrow. impact analysis, policy responses and recommendations. Retrieved from https://www.iesalc.unesco.org/

Viner, R.M., Russell, S.J., Croker, H., Packer, J., Ward, J., Stansfield, C. , Mytton, O., Bonell, C. \& Booy, R. (2020). School closure and management practices during coronavirus outbreaks including COVID-19: a rapid systematic review. The Lancet Child \& Adolescent Health, 4(5), 397-404.

World Bank Group Education (2020). The impact of the COVID-19 pandemic on education financing. coronavirus disease 2019 (COVID-19) situation report-57. Retrieved from https://www.worldbank.org/en/data/interactive/2020/03/24/world-bank education-and-covid-19 WHO (2020).

Worldmeters (2020). COVID-19 Coronavirus Pandemic. Retrieved from https://www.worldometers.info/coronavirus/

Yıldırım, A. \& Şimşek, H. (2011). Qualitative research methods in the social sciences. Ankara: Seçkin.

Yıldırım, K. (2010). Raising the quality in qualitative research. Elementary Education Online, 9(1), 79-92.

\section{Biographical Statements}

Tuğba Cevriye ÖZKARAL is Assist. Prof. at the Department of Social Studies Education, Necmettin Erbakan University, Turkey. Her studies focus on social studies teaching, teacher training, curriculum, textbook and comparative education.

Recep BOZYiĞíT is Assoc. Prof. at the Department of Geography Education, Necmettin Erbakan University,Turkey. His study area focuses on Geography Education, environment, Geomorphology and climate. 